\title{
Panduan Pelatihan dengan Strategi Belajar Terstruktur untuk Meningkatkan Disiplin Belajar Siswa SMA
}

\author{
Anis Tri Yuliana ${ }^{1}$, Nur Hidayah ${ }^{1}$, Carolina Ligya Radjah ${ }^{1}$ \\ ${ }^{1}$ Bimbingan dan Konseling-Universitas Negeri Malang
}

\begin{tabular}{l} 
INFO ARTIKEL \\
Riwayat Artikel: \\
Diterima: 03-07-2019 \\
Disetujui: 18-02-2020 \\
\hline
\end{tabular}

Kata kunci:

structured learning strategies; learning discipline;

high school student; strategi belajar terstruktur; disiplin belajar;

siswa SMA

\begin{abstract}
ABSTRAK
Abstract: This study aims to produce products that have been tested by media experts learning and expert guidance and counselling. The design used in this study was the development of Borg \& Gall (1983). Subjects of learning media experts are 2 people and guidance and counseling experts 2 people. The results of the assessment from learning media experts and expert guidance and counseling were analyzed with numerical data and non-numeric data. The final results of the assessment of learning media experts obtain a validity index of 0.94 with the category "high" and the final results of the assessment of guidance and counseling experts obtain a validity index of 0.87 in the "high" category. The findings of this study prove that the product training guide with structured learning strategies to improve student learning discipline is acceptable in a precise, clear and usable manner.
\end{abstract}

\begin{abstract}
Abstrak: Penelitian ini bertujuan untuk menghasilkan produk yang telah teruji ahli media pembelajaran dan ahli bimbingan dan konseling. Desain yang digunakan dalam penelitian ini adalah pengembangan Borg \& Gall. Subjek ahli media pembelajaran yaitu dua orang dan ahli bimbingan dan konseling dua orang. Hasil penilaian dari ahli media pembelajaran dan ahli bimbingan dan konseling dianalisis dengan data angka dan data non-angka. Hasil akhir penilaian ahli media pembelajaran memperoleh indeks validitas 0,94 dengan kategori "tinggi" dan hasil akhir penilaian ahli bimbingan dan konseling memperoleh indeks validitas 0,87 dengan kategori "tinggi". Temuan penelitian ini terbukti bahwa produk panduan pelatihan dengan strategi belajar terstruktur untuk meningkatkan disiplin belajar siswa berterima secara tepat, jelas, dan dapat digunakan.
\end{abstract}

\section{Alamat Korespondensi:}

Anis Tri Yuliana

Bimbingan dan Konseling

Universitas Negeri Malang

Jalan Semarang 5 Malang

E-mail: anistriyuliana@gmail.com

Pendidikan merupakan kegiatan yang sangat kompleks dan merupakan kebutuhan sepanjang hayat. Pendidikan melibatkan berbagai komponen yang berperan aktif terhadap kesuksesan pendidikan (Sakinah \& Haryati, 2014). Kesuksesan pendidikan yang dimaksudkan yaitu berkaitan dengan tercapainya tujuan pendidikan nasional yang diharapkan. Menurut UU No 20 Tahun 2003 mengatakan bahwa:

Pendidikan Nasional berfungsi mengembangkan kemampuan dan membentuk watak serta peradaban bangsa yang bermartabat dalam rangka mencerdaskan kehidupan bangsa, bertujuan untuk berkembangnya potensi peserta didik agar menjadi manusia yang beriman dan bertaqwa kepada Tuhan Yang Maha Esa, berakhlak mulia, sehat, berilmu, cakap, kreatif, mandiri, dan menjadi warga negara yang demokratis serta bertanggung jawab.

Tujuan pendidikan nasional yang diharapkan, salah satunya yaitu mampu membangun integritas kepribadian manusia seutuhnya dengan mengembangkan berbagai potensi secara terpadu. Keberhasilan dalam membangun kepribadian manusia seutuhnya akan memberikan dampak yang signifikan kepada diri sendiri, orang lain, bahkan Negara. Hal tersebut sesuai dengan pendapat Mulyasa (dalam Qomar, 2012) bahwa pendidikan memberikan kontribusi yang sangat besar terhadap kemajuan suatu bangsa dan membangun watak bangsa. Pencapaian tujuan pendidikan nasional harus disertai dengan proses dan proses inilah yang akan menjadi pembelajaran untuk menghasilkan manusia yang berkualitas sehingga mampu bersaing di era global seperti sekarang ini (Yasmin, 2016). Salah satu proses yang dapat dilakukan untuk mencapai tujuan pendidikan nasional yaitu dengan menumbuhkan perilaku disiplin. Disiplin merupakan bagian dari terwujudnya tujuan pendidikan secara umum dan menjadi sarana pendidikan (Prijodarminto, 1992). Disiplin berperan memengaruhi, mendorong, mengendalikan, mengubah, membina dan membentuk perilaku-perilaku tertentu sesuai dengan nilai-nilai yang ditanamkan, diajarkan, dan diteladankan (Tu'u, 2008). 
Disiplin menjadi sesuatu yang dicanangkan oleh berbagai institusi pemerintah baik dalam maupun luar negeri. Hal tersebut senada dengan yang disampaikan oleh Temitayo, Nayaya, \& Lukman (2013) bahwa masalah disiplin merupakan masalah umum yang memengaruhi sekolah diberbagai Negara di dunia dan diperingkatkan sebagai masalah utama di sekolah terutama tingkat sekolah menengah. Penelitian juga turut memperkuat bukti bahwa disiplin tampaknya terjadi dimana-mana di abad ke-21 ini, salah satunya yaitu terjadi pada sekolah menengah di Nigeria (Nakpodia, 2010). Begitupun dengan Indonesia, sebagai negara yang berkembang belum berada pada tingkat disiplin yang baik dan masih terus berusaha meningkatkan disiplin (Tu'u, 2008).

Disiplin dapat ditingkatkan melalui proses pelatihan dan pembelajaran yang mendorong pertumbuhan dan perkembangan manusia. Disiplin yang dimaksud dalam penelitian ini adalah disiplin belajar siswa di Sekolah Menengah Atas. Disiplin belajar adalah melaksanakan pedoman-pedoman yang baik dalam usaha belajar dengan penerapan cara belajar yang baik (Sari, 2017). Senada dengan pendapat tersebut, Kusuma \& Subkhan (2015) menyatakan bahwa disiplin belajar adalah sifat bertanggung jawab siswa terhadap suatu peraturan-peraturan. Di sekolah, permasalahan tentang disiplin diri dalam belajar yang terjadi dikalangan siswa masih sering ditemui terutama di tingkat pendidikan menengah atau lebih khususnya di Sekolah Menengah Atas. Hal tersebut dibuktikan dengan studi pendahuluan yang dilakukan oleh peneliti di SMA Negeri 2 Sumenep.

Berdasarkan hasil pengamatan, wawancara, dan penyebaran angket kepada siswa di SMA Negeri 2 Sumenep dapat disimpulkan bahwa masalah-masalah yang dialami siswa SMA Negeri 2 Sumenep yang berkaitan dengan disiplin belajarnya yaitu menunda-nunda dalam mengerjakan tugas/PR (70-80\%), berbicara dengan teman saat KBM berlangsung (50-60\%), tidak berkonsentrasi terhadap penjelasan yang disampaikan oleh guru (30-40\%), dan pergi ke toilet pada mata pelajaran yang tidak disenangi sampai satu mata pelajaran selesai (10-20\%). Data tersebut menunjukkan bahwa disiplin belajar siswa di SMA Negeri 2 Sumenep tergolong rendah. Rendahnya disiplin belajar yang terjadi pada siswa di SMA Negeri 2 Sumenep menjadi suatu hal yang sangat disayangkan karena apabila disimpulkan, disiplin belajar dapat memberikan keberhasilan-keberhasilan bagi siswa.

Keberhasilan-keberhasilan yang berkaitan dengan disiplin belajar merupakan kunci sukses bagi siswa terutama dalam meraih prestasi, namun sebaliknya siswa yang kurang memiliki disiplin diri dalam belajar akan menyebabkan kegagalan, frustasi, ketidakbahagiaan dalam hidup, dan tidak berprestasi (Tracy, 2017). Hal tersebut juga senada dengan yang disampaikan (Waschull, 2005) bahwa disiplin diri adalah salah satu faktor terpenting untuk menentukan keberhasilan siswa. Menurut Pasternak (2013), disiplin belajar sangat penting untuk penyesuaian siswa dalam belajar mandiri yang menuntut otonomi pribadi, kemandirian, dan kemampuan untuk mengambil tanggung jawab untuk menetapkan tujuan dan merencanakan kegiatan yang diperlukan untuk pencapaian siswa.

Pencapaian disiplin belajar bagi keberhasilan siswa diperkuat dengan berbagai penelitian. Costa (2015) menjelaskan bahwa disiplin belajar berpengaruh terhadap prestasi akademik dengan presentase yaitu sekitar 31,9 \% . (Kusuma \& Subkhan, 2015) dalam penelitiannya juga mengatakan bahwa faktor lain yang memengaruhi tinggi rendahnya prestasi belajar adalah disiplin belajar siswa dalam pembelajaran. (Gorbunovs, Kapenieks, \& Cakula, 2016) dalam penelitiannya juga menunjukkan bahwa disiplin diri merupakan faktor kunci yang memengaruhi siswa dan memungkinkan siswa mencapai tujuan. (Duckworth \& Seligman, 2005) turut menyatakan bahwa disiplin diri siswa yang dilakukan berdasarkan kesadaran memberikan keuntungan kepada siswa menjadi individu yang mandiri dalam mencapai tujuan keberhasilan. Dengan demikian, guru BK perlu memiliki cara atau strategi untuk melatih disiplin belajar siswa melalui pelayanan khusus dalam program bimbingan dan konseling.

Salah satu strategi yang bisa digunakan yaitu strategi belajar terstruktur. Strategi belajar terstruktur merupakan pendekatan pembelajaran yang dikembangkan dari teori belajar dan modifikasi tingkah laku dalam rangka pelatihan keterampilan perilaku yang lebih komprehensif dengan tahapan terstruktur (Goldstein, Sprafkin, \& Gershaw, 1976). Strategi belajar terstruktur dikembangkan sekitar tahun 1970-an untuk memberikan keterampilan sosial pada pasien-pasien psikiatrik kronis yang menderita kurangnya keterampilan sosial (Goldstein et al., 1976). Dalam perkembangannya, strategi belajar terstruktur kemudian tidak hanya di rumah sakit kesehatan mental karena model ini berkembang dari teori belajar sosial yang juga dapat diterapkan pada individu-individu untuk membentuk perilaku baru, salah satunya yaitu perilaku disiplin (Widyastuti \& Barida, 2016).

Penelitian-penelitian yang menunjukkan keefektifan strategi belajar terstruktur yaitu penelitian yang dilakukan oleh (Sugiyatno, 2003) hasil penelitiannya menunjukkan bahwa teknik belajar terstruktur yang digunakan dapat membantu meningkatkan keterampilan interpersonal siswa SMK. (Wahyuni, 2012) hasil penelitiannya menunjukkan bahwa strategi belajar terstruktur terbukti efektif dalam meningkatkan keterampilan dasar komunikasi calon konselor. Ahmad \& Hartati (2016) hasil penelitiannya menunjukkan bahwa hasil pretest dan posttest siswa yang diukur dengan skala self advocacy melalui belajar terstruktur terbukti efektif dalam meningkatkan keterampilan sosial. (Aisa, 2015) menghasilkan penelitian bahwa strategi belajar terstruktur terbukti efektif untuk meningkatkan empati siswa. (Latifah, 2015) juga menghasilkan penelitian yang menunjukkan bahwa strategi belajar terstruktur terbukti efektif untuk meningkatkan penyesuaian diri siswa di lingkungan kerja. Penelitian-penelitian yang telah dilakukan tersebut menunjukkan bahwa strategi belajar terstruktur merupakan salah satu strategi yang dapat digunakan untuk meningkatkan perilaku disiplin belajar siswa. 


\section{METODE}

Penelitian ini bertujuan untuk menghasilkan produk panduan pelatihan dengan strategi belajar terstruktur untuk meningkatkan disiplin belajar siswa SMA. Penelitian ini menggunakan model penelitian dan pengembangan dari (Borg \& Gall, 2003). Alasan pemilihan model penelitian dan pengembangan karena penelitian ini lebih menekankan pada keberterimaan produk baik dari segi format atau isi. Untuk mengetahui keberterimaan format dan isi tersebut, maka produk yang dihasilkan dalam penelitian ini harus di validasi oleh ahli .Ahli yang dilibatkan untuk melakukan validasi produk dari sisi format yaitu ahli media pembelajaran sedangkan ahli yang dilibatkan untuk validasi isi produk yaitu ahli bimbingan dan konseling.Penelitian ini hanya sampai tahap uji ahli yang nantinya produk yang dihasilkan berupa prototype panduan pelatihan dengan strategi belajar terstruktur untuk meningkatkan disiplin belajar siswa SMA.

Instrumen yang digunakan dalam penelitian ini adalah skala disiplin belajar. Skala disiplin belajar berisi sejumlah pernyataan yang harus dijawab oleh siswa dengan pilihan jawaban yaitu selalu (SL), sering (SR), kadang-kadang (KD), dan tidak pernah (TP). Skala disiplin belajar telah dilakukan validasi instrumen menggunakan bantuan IBM SPSS Versi 21 for windows yang menghasilkan 37 butir valid dan 23 butir tidak valid dari jumlah item sebelum divalidasi yaitu 60 butir dan reliabilitas cronbach's alpha sebesar 0,906.

Setelah dilakukan proses penghitungan rerata dan presentase, maka diketahui hasil presentase gambaran disiplin belajar siswa SMA. Hasil tersebut diklasifikasikan berdasarkan rubrik klasifikasi pencapaian disiplin belajar siswa SMA.Rubrik pengklasifikasian tersebut tersaji pada tabel 1 dan hasil pengklasifikasian tersebut merupakan gambaran pencapaian disiplin belajar siswa SMA.

Tabel 1. Rubrik Klasifikasi Disiplin Belajar Siswa

\begin{tabular}{lc}
\hline Persentase & Klasifikasi \\
\hline $50-100 \%$ & Tinggi \\
$20-49 \%$ & Sedang \\
$0-19 \%$ & Rendah \\
\hline
\end{tabular}

Subjek ahli media pembelajaran ada dua ahli dan ahli bimbingan konseling dalam penelitian ini juga ada dua ahli. Masing-masing ahli akan memberikan penilaian terhadap prototype yang dihasilkan dari penelitian ini dari segi format dan isi. Instrumen yang digunakan yaitu instrumen penilaian ahli dengan empat pilihan jawaban yaitu dari angka $1-4$. Teknik analisis data berdasarkan hasil penilaian ahli media pembelajaran dan ahli bimbingan dan konseling menggunakan teknik analisis kesepatakan antar rater dari (Aiken, 1980) untuk data angka dan data non-angka dengan analisis deskriptif interpretatif . Kategori hasil penilaian kelayakan produk disajikan pada tabel 2.

Tabel 2. Kategori Hasil Penilaian Kelayakan Produk

\begin{tabular}{cc}
\hline Persentase & Klasifikasi \\
\hline $0.81-1.00$ & Tinggi \\
$0.41-0.80$ & Sedang \\
$0.00-0.40$ & Rendah \\
\hline
\end{tabular}

\section{HASIL}

Hasil analisis data diperoleh dari penilaian ahli media pembelajaran dan ahli bimbingan dan konseling. Penilaian dari ahli media pembelajaran dilakukan oleh dua orang ahli dengan hasil data angka dan data non-angka sebagai berikut. Data angka yang diberikan oleh ahli media pembelajaran ahli 1 dan 2 disajikan pada tabel 3. Data angka yang diberikan oleh ahli bimbingan dan konseling sebagai ahli 1 dan 2 disajikan pada tabel 4. 
Tabel 3. Hasil Penilaian Ahli Media Pembelajaran

\begin{tabular}{|c|c|c|c|c|}
\hline \multirow{2}{*}{ Aspek Penilaian } & \multicolumn{2}{|c|}{ Skor } & \multirow{2}{*}{$\begin{array}{c}\text { Indeks } \\
\text { Validitas Ahli }\end{array}$} & \multirow{2}{*}{ Interpretasi } \\
\hline & Ahli 1 & Ahli 2 & & \\
\hline \multicolumn{5}{|l|}{ Aspek Ketepatan } \\
\hline 1. Ketepatan ukuran buku yang digunakan & 4 & 4 & 1,00 & Tinggi \\
\hline 2. Ketepatan desain sampul yang digunakan dengan sasaran pengguna & 4 & 4 & 1,00 & Tinggi \\
\hline 3. Ketepatan desain isi buku yang digunakan & 4 & 4 & 1,00 & Tinggi \\
\hline 4. Ketepatan gambar yang dipilih dalam sampul & 4 & 4 & 1,00 & Tinggi \\
\hline 5. Ketepatan pemilihan warna dalam sampul & 3 & 4 & 0,83 & Tinggi \\
\hline 6. Ketepatan tata letak penyajian (tulisan dan gambar) dalam sampul & 4 & 4 & 1,00 & Tinggi \\
\hline 7. Ketepatan keruntutan bab penyajian dalam buku panduan & 3 & 4 & 0,83 & Tinggi \\
\hline 8. Ketepatan spasi yang digunakan dalam buku panduan & 3 & 4 & 0,83 & Tinggi \\
\hline 9. Ketepatan pemilihan jenis font yang digunakan dalam buku panduan & 4 & 4 & 1,00 & Tinggi \\
\hline 10. Ketepatan gambar yang digunakan dengan subyek (siswa SMA) & 4 & 4 & 1,00 & Tinggi \\
\hline Hasil Akhir Aspek Ketepatan & 37 & 40 & 0,94 & Tinggi \\
\hline \multicolumn{5}{|l|}{ Aspek Kejelasan } \\
\hline 11. Kejelasan warna yang digunakan sebagai latar sampul & 3 & 4 & 0,83 & Tinggi \\
\hline 12. Kejelasan tulisan dalam sampul & 4 & 4 & 1,00 & Tinggi \\
\hline 13. Kejelasan identitas pengembang dan nama lembaga & 4 & 4 & 1,00 & Tinggi \\
\hline 14. Kejelasan gambar yang dipilih dengan judul buku panduan & 4 & 4 & 1,00 & Tinggi \\
\hline 15. Kejelasan jenis tulisan dalam sampul & 3 & 3 & 0,83 & Tinggi \\
\hline 16. Kejelasan jenis tulisan dalam isi panduan & 4 & 3 & 0,83 & Tinggi \\
\hline 17. Kejelasan ukuran font dalam sampul & 4 & 4 & 1,00 & Tinggi \\
\hline 18. Kejelasan ukuran font dalam isi panduan & 4 & 4 & 1,00 & Tinggi \\
\hline 19. Kejelasan sasaran pengguna panduan dalam sampul & 4 & 4 & 1,00 & Tinggi \\
\hline 20. Kejelasan letak halaman di daftar isi & 4 & 4 & 1,00 & Tinggi \\
\hline Hasil Akhir Aspek Kejelasan & 38 & 38 & 0,94 & Tinggi \\
\hline Hasil Akhir Penilaian Ahli Media Pembelajaran & 75 & 78 & 0,94 & Tinggi \\
\hline
\end{tabular}

Tabel 4. Hasil Penilaian Ahli Bimbingan dan Konseling

\begin{tabular}{|c|c|c|c|c|c|}
\hline \multirow[b]{2}{*}{ No. } & \multirow[b]{2}{*}{ Aspek Penilaian } & \multicolumn{2}{|c|}{ Skor } & \multirow{2}{*}{$\begin{array}{c}\text { Indeks } \\
\text { Validitas } \\
\text { Ahli }\end{array}$} & \multirow[b]{2}{*}{ Interpretasi } \\
\hline & & $\begin{array}{c}\text { Ahli } \\
1\end{array}$ & $\begin{array}{c}\text { Ahli } \\
2\end{array}$ & & \\
\hline \multicolumn{6}{|c|}{ Aspek Ketepatan } \\
\hline 1. & Ketepatan isi ucapan terima kasih & 4 & 4 & 1,00 & Tinggi \\
\hline 2. & Ketepatan rasional yang dipaparkan & 3 & 4 & 0,83 & Tinggi \\
\hline 3. & Ketepatan tujuan dengan yang diharapkan & 4 & 4 & 1,00 & Tinggi \\
\hline 4. & Ketepatan pemaparan petunjuk umum dan petunjuk khusus & 3 & 4 & 0,83 & Tinggi \\
\hline 5. & Ketepatan materi dengan indikator yang diukur & 3 & 3 & 0,67 & Sedang \\
\hline & $\begin{array}{l}\text { Ketepatan materi dengan standar kompetensi dan kompetensi dasar pada jenjang } \\
\text { SMA }\end{array}$ & 3 & 4 & 0,83 & Tinggi \\
\hline 7. & Ketepatan skala disiplin diri dalam belajar dengan tujuan pengukuran & 4 & 3 & 0,83 & Tinggi \\
\hline 8. & Ketepatan skenario yang digunakan dengan tujuan yang diharapkan & 4 & 3 & 0,83 & Tinggi \\
\hline & Ketepatan pemberian tugas rumah dengan tujuan yang diharapkan & 4 & 3 & 0,83 & Tinggi \\
\hline 10. & Ketepatan penggunaan bahasa yang digunakan untuk siswa & 3 & 3 & 0,67 & Sedang \\
\hline Hasi & Akhir Aspek Ketepatan & 35 & 35 & 0,83 & Tinggi \\
\hline
\end{tabular}


Tabel 4. Hasil Penilaian Ahli Bimbingan dan Konseling (Lanjutan)

\begin{tabular}{|c|c|c|c|c|}
\hline \multicolumn{5}{|l|}{ Aspek Kejelasan } \\
\hline Kejelasan prosedur pelatihan dari pertemuan pertama sampai terakhir & 4 & 4 & 1,00 & Tinggi \\
\hline 2. Kejelasan pendeskripsian kalimat di sampul belakang & 3 & 3 & 0,67 & Sedang \\
\hline 3. Kejelasan runtutan penyampaian gagasan dalam rasional & 3 & 3 & 0,67 & Sedang \\
\hline 4. Kejelasan tujuan dari panduan & 4 & 4 & 1,00 & Tinggi \\
\hline 5. Kejelasan sasaran pengguna panduan & 4 & 4 & 1,00 & Tinggi \\
\hline 6. Kejelasan petunjuk umum dan khusus panduan & 4 & 4 & 1,00 & Tinggi \\
\hline 7. Kejelasan strategi pelatihan yang digunakan & 4 & 4 & 1,00 & Tinggi \\
\hline 8. Kejelasan jadwal kegiatan pelatihan dalam table & 4 & 4 & 1,00 & Tinggi \\
\hline $\begin{array}{l}\text { 9. Kejelasan petunjuk pengisian instrumen skala disiplin diri dalam } \\
\text { belajar }\end{array}$ & 4 & 4 & 1,00 & Tinggi \\
\hline 10. Kejelasan daftar rujukan yang digunakan & 3 & 4 & 0,83 & Tinggi \\
\hline Hasil Akhir Aspek Kejelasan & 37 & 38 & 0,91 & Tinggi \\
\hline Hasil Akhir Penilaian Ahli BK & 72 & 73 & 0,87 & Tinggi \\
\hline
\end{tabular}

\section{PEMBAHASAN}

Berdasarkan hasil penilaian yang diberikan oleh ahli media pembelajaran pada tabel 3 diperoleh indeks validitas ketepatan yaitu 0,94 dan indeks validitas kejelasan yaitu 0,94 dengan interpretasi "tinggi". Selain itu, penilaian secara keseluruhan dari dua ahli media pembelajaran diperoleh indeks validitas yaitu 0,94 dengan interpretasi "tinggi". Indeks validitas ketepatan dan kejelasan yang diperoleh menunjukkan bahwa panduan pelatihan dengan strategi belajar terstruktur untuk meningkatkan disiplin belajar siswa SMA ini dapat dinyatakan sebagai media pembelajaran yang sangat layak digunakan oleh guru BK di sekolah. Data non-angka yang telah didapatkan dari ahli media pembelajaran yaitu panduan masih memiliki kekurangan, ketidak tepatan, dan ketidak konsistenan dalam hal pewarnaan, penomoran, dan tata tulis (sudah direvisi). Secara umum, ahli media pembelajaran telah menyetujui bahwa produk telah siap untuk digunakan dari sisi media.

Berdasarkan hasil penilaian yang diberikan oleh ahli bimbingan dan konseling pada tabel 4 diperoleh indeks validitas ketepatan yaitu 0,83 dan indeks validitas kejelasan yaitu 0,91 dengan interpretasi "tinggi". Selain itu, penilaian secara keseluruhan dari dua ahli bimbingan dan konseling diperoleh indeks validitas yaitu 0,87 dengan interpretasi "tinggi". Indeks validitas ketepatan dan kejelasan yang diperoleh menunjukkan bahwa panduan pelatihan dengan strategi belajar terstruktur untuk meningkatkan disiplin belajar siswa SMA ini dapat dinyatakan bahwa produk sangat layak digunakan oleh guru BK di sekolah dari sisi materi dalam pemberian layanan bimbingan kelompok meskipun ada beberapa saran yang perlu diperbaiki. Data non-angka yang berupa saran dari ahli bimbingan dan konseling berkaitan dengan materi/topik pertemuan, pertemuan terakhir bersifat joy of learning, daftar rujukan tentang strategi belajar terstruktur harus dicantumkan di daftar rujukan, pembahasan tugas yang diberikan pada pertemuan sebelumnya, mengajak siswa untuk membuat kesimpulan tentang kegiatan, dan pada penyusunan butir dalam skala disiplin belajar untuk menghindari penggunaan kata "selalu" dan mengakomodir keragaman belajar siswa (sudah direvisi).

\section{SIMPULAN}

Hasil penelitian ini menunjukkan ketepatan, kejelasan, dan kelayakan produk dari sisi format dan isi berdasarkan penilaian yang diberikan oleh ahli media pembelajaran dan ahli bimbingan dan konseling. Berdasarkan hasil penelitian ini, diajukan saran pemanfaatan dan pengembangan lebih lanjut. Saran pemanfaatan yaitu ditujukan kepada guru BK hendaknya memahami prosedur dan materi bimbingan yang ada dalam panduan ini agar dapat membantu siswa meningkatkan disiplin belajarnya sehingga dapat meraih prestasi akademik, dan guru BK dapat menggunakan model simbolik atau melalui video/film/sinema edukasi yang menggambarkan disiplin belajar siswa karena dalam panduan ini model yang digunakan adalah model langsung. Saran pengembangan lebih lanjut yaitu disarankan untuk melanjutkan penelitan ini ke tahap calon pengguna (guru BK), dan melakukan uji keefektifan.

\section{DAFTAR RUJUKAN}

Ahmad., \& Hartati. (2016). Penerapan Teknik Structure Learning Approach Dalam Meningkatkan Self Advocacy Mahasiswa Prodi BK IKIP Mataram. Jurnal Realita, 1(2503-1708), 117-127.

Aiken, L. R. (1980). Content Validity and Reliability of Single Items or Questionnaires. Educational and Psychological Measurement, 40(4), 955-959. https://doi.org/10.1177/001316448004000419

Aisa, A. (2015). Keefektifan Structured Learning Approach untuk Meningkatkan Empati Siswa. Tesis tidak diterbitkan Universitas Negeri Malang, Malang.

Borg, W. R., \& Gall, M. D. (2003). Educational Research (Seventh edition). Educational Research: An Introduction. 
Costa, A. (2015). Pengaruh Motivasi Belajar, Disiplin Belajar, dan Penyesuaian Diri terhadap Prestasi Akademik Mahasiswa Timor Leste yang Kuliah di Malang. Tesis tidak diterbitkan. Universitas Negeri Malang, Malang.

Duckworth, A. L., \& Seligman, M. E. P. (2005). Self-Discipline Outdoes IQ in Predicting Academic Performance of Adolescents. Psychological Science, 16(12), 939-944. https://doi.org/10.1111/j.1467-9280.2005.01641.x

Goldstein, A. P., Sprafkin, R. P., \& Gershaw, N. J. (1976). Structured Learning Therapy: Training for Community Living. Psychotherapy: Theory, Research \& Practice, 16(2), 199-203. https://doi.org/10.1037/h0086048

Gorbunovs, A., Kapenieks, A., \& Cakula, S. (2016). Self-discipline as a Key Indicator to Improve Learning Outcomes in elearning Environment. Procedia - Social and Behavioral Sciences, 231(November), 256-262. https://doi.org/10.1016/j.sbspro.2016.09.100

Kusuma, Z. L., \& Subkhan. (2015). Pengaruh Motivasi Belajar dan Kedisiplinan Belajar terhadap Prestasi Belajar Mata Pelajaran Akuntansi Siswa Kelas XI IPS SMA N 3 Pati Tahun Pelajaran 2013/2014. Economics Development Analysis Journal, 4(2), 164-171. https://doi.org/http://dx.doi.org/10.1093/ageing/25.2.97

Latifah, L. (2015). Efektivitas Teknik SLA (Structured Learning Approach) untuk Meningkatkan Penyesuaian Diri Siswa Prakerin di Lingkungan Universitas Kanjuruhan Malang. JKI (Jurnal Konseling Indonesia), 1(1), 61-67.

Nakpodia, E. D. (2010). Teachers` Disciplinary Approaches to Students Discipline Problems in Nigerian Secondary Schools. International NGO Journal,5(6), 144-151.

Pasternak, R. (2013). Discipline Learning Skills and Academic Achievement. Journal of Arts and Education, 1(1), 1-11.

Sakinah, N., \& Haryati, T. (2014). Pengaruh Disiplin Belajar, Motivasi Belajar, dan Lingkungan Keluarga terhadap Prestasi Belajar Mata Pelajaran Ekonomi Siswa Kelas X SMA N 2 Kudus Tahun Ajaran 2013/2014. Economic Education Analysis Journal, 3(2), 379-384.

Sugiyatno. (2003). Pengembangan Panduan Pelatihan Ketrampilan Interpersonal bagi Siswa SMK. Tesis tidak diterbitkan. Universitas Negeri Malang, Malang.

Temitayo, O., Nayaya, M. A., \& Lukman, A. A. (2013). Management of Disciplinary Problems in Secondary Schools: JalingoMetropolis in Focus. Global Journal of Human Social Science Linguistics \& Education Version 1, 13(14), 6-19.

Tu’u, T. (2008). Peran Perilaku Disiplin Pada Perilaku dan Prestasi Siswa (Kristiadi Wibowo, Ed.). Jakarta: PT Grasindo.

Wahyuni. (2012). Pengembangan Panduan Pelatihan Keterampilan Dasar Komunikasi Calon Konselor dengan Structured Learning Approach.

Waschull, S. B. (2005). Predicting Success in Online Psychology Courses: Self-Discipline and Motivation. Teaching of Psychology, 32(3), 190-192. https://doi.org/10.1207/s15328023top3203_11

Widyastuti., \& Barida. (2016). Prosiding Seminar Nasional LP3M (Lembaga Pengembangan, Pembelajaran, dan penjaminan Mutu) Surabaya, 5 November 2016 Membangun Karakter untuk Memperkokoh Persatuan dan Kesatuan Bangsa. (November), 62-73. 